\title{
FEDERAL ENACTMENT OF THE UNIFORM COMMERCIAL CODE
}

\author{
ROBERT BRAUCHER*
}

The Uniform Commercial Code in the Proposed Final Draft, Spring 1950, contains alternative Sections I-ro5, one labelled "State Version," one "Federal Version." The latter is "intended for use when the Code is introduced in the Congress of the United States." The Federal Version makes provisions for "federal territory" and for "interstate or foreign commerce."

"Federal territory" means "the District of Columbia and any territory or possession of the United States not having its own legislature." For the most part, the federal-territory provisions merely substitute "federal territory" wherever "this state" appears in the State Version. But the Articles on Secured Transactions and Bulk Transfers are omitted entirely from the Federal Version. Where some Articles are made applicable if "the transaction" occurs within a state, they are applicable instead if "the contract" occurs within federal territory. And the Articles on Commercial Paper and on Bank Deposits and Collections apply if the contract involves commercial paper which is "to be performed" within federal territory; no corresponding phrase appears in the State Version. No reason is given for these differences.

The Federal Version also makes each Article, except those on Secured Transactions and Bulk Transfers, applicable "whenever any contract or transaction" within its terms

is made or occurs after the effective date of this Act and the contract

(a) is in or affects interstate or foreign commerce; ...

I am informed that the words "or affects" were stricken at the May 1950 meeting of the American Law Institute. In addition, there is a provision that

(6) Whenever a contract, instrument, document, or security has points of contact with one or more nations in addition to the United States, its territories and possessions

(a) the parties may agree that the law of any other nation having such a contract shall govern their rights and duties; and

(b) in the absence of such agreement this Act governs.

The discussion here is primarily directed at the provision for contracts in interstate or foreign commerce.

*A.B. 1936, Haverford College; LL.B. 1939, Harvard University. Professor of Law, Harvard University. 


\section{Desirability of Federal Legislation}

Uniformity of commercial law through federal action is not a new idea. In 1842, in Swift v. Tyson, ${ }^{1}$ the Supreme Court held that in disputes between citizens of different states the federal courts were free to decide questions in the law of commercial paper without regard to the vagaries of the common-law decisions of state courts. On matters of local usage, said Mr. Justice Story, the rule was different, but

The law respecting negotiable instruments may be truly declared in the language of Cicero, adopted by Lord Mansfield ... to be in a great measure, not the law of a single country only, but of the commercial world.

Unfortunately the doctrine of Swift v. Tyson, while it produced uniformity between states, introduced lack of uniformity within states. New York adhered for nearly sixty years to the rule of commercial paper rejected by the Supreme Court in that case, until the rule was abolished by the Negotiable Instruments Law. ${ }^{2}$ And state law was final if both parties were residents of the same state, or if the amount in controversy was too small to give the federal courts jurisdiction. Moreover, when the state law became statutory, the doctrine of Swift $v$. Tyson gave way, and federal courts were bound to follow state decisions interpreting the statute. ${ }^{3}$ Partly for these reasons, and partly because the doctrine had been extended too far beyond the bounds of commercial law, the Supreme Court abandoned the doctrine in 1938 in Erie Railroad v. Tompkins. ${ }^{4}$

Uniformity by act of Congress under the commerce power was also urged many years ago. In I89o a bill was introduced in the House of Representatives "to regulate commerce among the several states, and to codify the law relating to bills of exchange and other commercial paper." The bill was referred to the Committee on the Judiciary, and seems not to have been reported out of committee. Also in 1890 , Senator Turpie predicted ${ }^{6}$

That the whole mass of merchantable paper known as negotiable by the law merchant, made at one place, negotiable at another, payable at another, transcending in its negotiation State lines, will be remitted to Congressional action, and with respect to its creation, its formation, its negotiation, with respect to all the rights and liabilities which may arise under it, the people, stunned with the eternal dissonance of conflicting decisions and judgments of forty-eight or fifty tribunals of last resort in the States upon the subject of interstate negotiable paper, will require Congress to act therein....

In I8gI the Committee on Uniform State Laws of the American Bar Association considered, among other objections to the drive for uniformity, the suggestion that ${ }^{7}$

${ }^{2}$ I6 Pet. I (U. S. 1842 ).

${ }^{2}$ See Kelso \& Co. v. Ellis, 224 N. Y. 528, 536, I2I N. E. $364,366-67$ (I9r8).

${ }^{3}$ See, e.g., Burns Mortgage Co. v. Fried, 292 U. S. 487, 493-95 (1934).

304 U. S. 64 (1938).

'H. R. 6957, 5Ist Cong., Ist Sess., 21 Conc. Rec. I374 (1890).

- 2 I Conc. Rec. 2556-57 (I890).

${ }^{7}{ }_{14}$ A. B. A. Rep. 373-74 (I89x). 
the results of uniformity can be better and more permanently secured by national unification-by Congressional action, and, if necessary, by constitutional amendment-than by separate state action. That this method would have the advantage of more complete uniformity and of permanency, if it were practicable, must be admitted. But the insuperable difficulties in the way of positive national action, at present, are so apparent . . . that this alternative is really out of the question.

The principal difficulty referred to was that federal legislation would trespass on the powers of the states. The Committee's attention was directed primarily to marriage and divorce law, but it said that "the same difficulty lies in the path of national action in the other matters in question," which included negotiable instruments. As applied to commerce among the several states, that statement was probably too broad when it was made. Certainly it has little force today, when it can no longer be said that insurance is not commerce. ${ }^{8}$ The constitutional power of Congress to act on commercial law in interstate transactions is clear; it deserves no further discussion.

Federal law today provides much of the framework within which the Code must operate. The Bank Collection Code came to grief because state law could not provide for the distribution of the assets of insolvent national banks. ${ }^{9}$ Federal Reserve Regulation $J$ and the rules of the Federal Deposit Insurance Corporation are vital factors in bank collections. ${ }^{10}$ Forms of railroad bills of lading have been prescribed by the Interstate Commerce Commission; ${ }^{11}$ there is a Federal Bills of Lading Act, enacted in I9I6, identical for the most part with the Uniform Bills of Lading Act. ${ }^{12}$ The law of security must take account of the Bankruptcy Act, which includes the substance of the Uniform Fraudulent Conveyance Act, adopted by only twenty states. $^{13}$ The list of federal statutes could be extended almost indefinitely.

Moreover, the $189 x$ report went on $:^{14}$

And, in truth, if national action, at least by way of prohibitory amendments to the constitution, is finally found to be the true solution of the problem, what better preparation can be suggested than the concurrent action of the various State Commissions; and who more likely to see the necessity for national action, if it exists, than these very Commissions?

The Commissioners on Uniform State'Laws have now seen that necessity, and their Uniform Acts have prepared the way for federal enactment of the proposed Code. Their efforts have produced great progress toward uniformity. But progress

'United States v. South-Eastern Underwriters Ass'n, 322 U. S. 533 (1944).

${ }^{9}$ Jennings v. United States Fidelity \& Guaranty Co., 294 U. S. 216 (1935).

${ }^{10}$ See Leary, Deferred Posting and Delayed Returns-The Current Check Collection Problem, 62 HaRv. L. REv. 905 (1949).

${ }^{11}$ In the Matter of Bills of Lading, 52 I.C.C. 671 (I9rg); Domestic Bill of Lading and Livestock Contract, 64 I.C.C. 357 (I92I).

${ }^{12} 39$ Stat. 538 (I916), 49 U. S. C. $\$ \$ 8 I-124$ (1946); see 4 UniforMr Laws ANn. (1922).

${ }^{13}$ Bankruptcy Act Section 67d, 54 STAT. 835 (1940), xI U. S. C. \$107d (1946); sec 9 U. L. A. 163 (Supp. 1949).

${ }^{14}$ See note 7, supra, at 374 . 
has been slow, and uniformity is by no means complete, as is shown by the accompanying table..$^{15}$

\begin{tabular}{|c|c|c|c|}
\hline $\begin{array}{c}\text { Number } \\
\text { of } \\
\text { States }\end{array}$ & Promulgated & $\begin{array}{c}\text { Last } \\
\text { Enacted }\end{array}$ & Interval \\
\hline Negotiable Instruments Law. ......48 & $\mathrm{r} 897$ & Ig24 & 27 years \\
\hline Uniform Warehouse Receipts Act...48 & Igo6 & $x 945$ & 39 years \\
\hline Uniform Sales Act............ 34 & 1906 & I94I & 35 years \\
\hline Uniform Bills of Lading Act.....3I & rgog & 1947 & $3^{8}$ years \\
\hline Uniform Stock Transfer Act.......48 & rgog & 1947 & $3^{8}$ years \\
\hline Uniform Conditional Sales Act..... ro & xgr 8 & 1945 & 27 years \\
\hline Uniform Trust Receipts Act......27 & r933 & I949 & I6 years \\
\hline
\end{tabular}

The table exaggerates somewhat the uniformity achieved, for it leaves out of account numerous amendments made in individual states. On the other hand, it does not include the statutes proposed by the American Bankers Association, which have been widely enacted. ${ }^{16}$ The Bank Collection Code was enacted by ig states between I929 and I937; the Deferred Posting Statute was passed by at least 34 states during their 1949 legislative sessions. Bankers' statutes of more limited scope have also had some success, including acts on Fictitious Payees, Payment of Stale Checks, Time Limit on Stop-Payment, and others. Other statutes not promoted by the Commissioners have varied more widely: for example, the Bulk Sales Acts passed in every state between 1899 and I9I9, the statutes on assignment of accounts receivable, and the "factor's lien" statutes passed in some twenty states between I938 and $1947^{17}$

One of the weaknesses of uniform state legislation has been the difficulty of preserving uniformity in amendment. The best-drafted of laws cannot be expected to be eternal. Usages and attitudes change. Litigated cases raise unforeseen difficulties when there is only one court of last resort; when there are many, conflicts of interpretation arise. Professor Beutel reports such conflicts under some 75 sections of the Negotiable Instruments Law. ${ }^{18}$ But amendments decrease uniformity, at least temporarily, unless all the enacting states amend simultaneously.

The problem is illustrated by amendments which the Commissioners recommended in I922. They proposed to amend two sections of the Sales Act and three sections of the Warehouse Receipts Act to conform to the Bills of Lading Act. In the ensuing forty-five years, 18 of the 26 states which have enacted all three Acts have made some amendment, but only ro have amended both the Sales Act and the Warehouse Receipts Act. Thus, in addition to the common-law rules which still prevail in some states, there are several versions of the Uniform Acts now in force,

\footnotetext{
${ }^{16}$ The table has been compiled from the latest available pocket supplements to the Uniform Laws Annotated.

${ }^{16}$ See Thomas B. Paton, Digest of Legal Opinions (1940), and looseleaf Supplement.

${ }^{17}$ See CCH, Conditional Sale Chattel Mortgage Reporter.

${ }^{18}$ Beutel's Brannan, Negotiable Instruments Law 89 (7th ed. 1948).
} 
all of which have been approved by the Commissioners at one time or another. And independent amendments in single states still further impair uniformity.

The proposed Code is no mere list of specific amendments to cure ambiguities and conflicts of authority; it is a sweeping revision and reform in the light of fifty years of experience under the uniform laws. It seems likely that state legislatures will be no less hesitant to pass it than they were to pass comparatively minor amendments. In the absence of Congressional action, then, one could anticipate a fifty-year interval during which various common-law rules would prevail in some states, several versions of some or all of the uniform acts would prevail in others, and the Code, with or without amendments, would be in force in still others. The principal benefit would be the creation of a vast experimental laboratory for the conflict of laws.

Federal enactment changes the picture entirely. It is often of no great consequence to a Boston merchant or to his lawyer whether his transactions with Boston customers are governed by the same rules which govern merchants and customers in Chicago or Los Angeles. Uniformity in this sense may be important to our great nation-wide corporate enterprises, but they have learned to operate without it. It is far more important to be sure what rules govern transactions between the Boston merchant and the Chicago merchant, and to know that those rules will be the same in the courts in both places. This is the uniformity Mr. Justice Story undoubtedly hoped to achieve, though by a different route.

If uniformity is achieved in interstate transactions, it may be convenient to the Boston merchant to have local transactions governed by the same rules, if only to avoid bearing in mind two sets of rules. For this reason, for example, a state might hesitate to adopt the new Code for bills of lading unless there were some assurance that Congress would enact the same rules for interstate shipments. But once Congress has acted, Massachusetts need not wait for Arizona or Idaho.

These considerations lead almost inescapably to the conclusion, not that enactment by Congress is desirable, but that enactment without an act of Congress is undesirable. If the Code is to become law anywhere without causing more trouble than it cures, it must be enacted by Congress before or soon after the first state acts.

II

Scope of Federal Coverage

In May 1949 the proposal was to apply the federal version of the Code to "any contract or transaction" which "is in or affects interstate commerce," or "whenever the contract, instrument or document states in terms or in substance that it is subject to the Uniform Commercial Code or any Article thereof." Objection is said to have been made to the provision as to foreign commerce, on the ground that it might raise difficulties in our foreign relations. Literally a shipment from Argentina to Great Britain can be said to "affect" the foreign commerce of the United States if American suppliers make completing shipments. An Argentine shipper who was 
subjected to American law by an American court on such a ground might well complain to his Foreign Office at home. If his complaint fell on sympathetic ears, the dispute might have to be handled through diplomatic channels.

The only change on this point in the May I950 draft was the provision that the parties might agree, in the case supposed, that Argentine or British law would apply; the Code would apply only "in the absence of such agreement." That provision does not seem to meet the difficulty. The parties to an Argentine or British contract may be permitted to some extent to adopt American law for their agreement. But that does not make it proper for the United States to impose such an agreement upon them by virtue of their silence. Aside from possible questions of the power of Congress to adopt such a doctrine, there seems to be no compelling need for Congress to exercise its power in any such sweeping fashion.

The proposal raised similar difficulties domestically. It is hard to imagine a less well-defined boundary than that separating contracts which do from those which do not "affect" interstate commerce. Congress has power to punish conspiracies to restrain interstate commerce, to regulate labor relations where disputes may shut it down, to set minimum wages in the production of goods for commerce, to fix production quotas which will maintain prices in an interstate market. In each case the type of effect on commerce which is meant is comparatively clear. But the proposed Code gave no answer to the question, "affect" in what way?

Conceivably Congress has power, for example, to make the Code applicable to the sale of a five-cent candy bar by a local drugstore whenever competing candy bars are shipped in from other states. Did the proposal mean to cover such a sale? If it did, better statutory language is found in the Lanham Act, applicable to trade-marks "used in commerce," which defines "commerce" to mean "all commerce which may lawfully be regulated by Congress."19

If Congress ought to enact the Code as broadly as it constitutionally can, there seems to be no reason to rely solely on the commerce power. Why not also exhaust the bankruptcy and tax powers, and the powers over the mails, the currency, and the federal courts? But no reason appears for such sweeping action. It is a major innovation for Congress to enact the Code at all. The reasons why Congress should act as to interstate transactions have been outlined above. Should not the initial legislation be tailored to the felt need? Cannot the question whether convenience requires local law to conform to interstate law be left to state legislatures, at least until there has been some experience with federal codification?

One is led to suspect that one of the purposes of the sweeping proposal was to threaten such jurisdictional confusion that the states would be obliged to enact the Code in self-defense. Otherwise every petty commercial dispute would raise an issue of constitutional law. The proposal may have been attractive to its sponsors as a labor-saving device, but it seems clearly illegitimate. There is no justification here

${ }^{10} 60$ STAT. 427 (1946), 15 U. S. C. §§ro5I, Ir27 (1946). 
for coercion as a substitute for persuasion of state legislatures. And if there were, it would be unfortunate to run the risk that Congress would refuse to act at all by asking it to do too much.

The foregoing observations are not made in the disciplinary spirit which led officers like Captain Bligh to insist that the proper number of lashes be administered to a dead sailor. It seems safe to predict that Congress will not be asked to apply the Code to contracts which "affect" commerce. But much of the difficulty remains when the words "or affect" are excised. The Code is still to apply to any contract "in interstate or foreign commerce." The proposal still lacks precision. Doubtless the Supreme Court could eventually fashion acceptable rules of coverage from such raw material, but only after years of wasteful jurisdictional dispute.

There are of course precedents for the regulation of transactions "in commerce." The Fair Labor Standards Act provides minimum wages for employees "engaged in commerce," and defines "commerce" rather broadly as "trade, commerce, transportation, transmission, or communication among the several States or from any State to any place outside thereof."20 If certainty as to coverage is important, that provision is not a very good model; and the fact that it applies to a continuing employment relation makes it more certain than the Code provision, which would apply to isolated contracts. Similarly, the Perishable Agricultural Commodities Act, licensing dealers "engaged in the business" of buying or selling "in interstate or foreign commerce," defines its coverage of transactions in terms of the "current of commerce usual in the trade" in a particular commodity. ${ }^{21}$ Such a definition is less appropriate in a Code not limited to the produce trade, or a Code which may cover isolated transactions. More in point is the United States Arbitration Act, validating arbitration clauses in contracts "evidencing a transaction involving commerce"; 22 but uncertainty of scope seems less important in such a narrow statute than in a comprehensive Code. On the other hand, the scope provision of the Federal Bills of Lading Act, limited to "transportation of goods" across state lines, ${ }^{23}$ seems too narrow for the Code.

It may be appropriate here to suggest a more precise provision. The federal Code should be limited to interstate and foreign transactions; coverage should turn on the facts of the transaction, not on currents of commerce, competitive conditions, or the mental state of one of the parties. As to foreign transactions, the Code should be limited to cases where part of the transaction takes place within the United States, and the provision for contracting out of the Code should be retained. As to domestic transactions, it should apply to every case where there is some basis for applying the laws of more than one state.

${ }^{20} 52$ STAT. 1060 (1938), as amended, 29 U. S. C. $\$ \$ 203,206$ (1946).

${ }^{21} 46$ STAT. 531 (1930), as amended, 7 U. S. C. A. $\$ \$ 499$ a et seq. (1946).

2243 StAT. 883 (1925), as amended, 9 U. S. C. $\$ \$ 1,2$ (1946).

${ }^{23} 39$ STAT. 538 (I916), 49 U. S. C. \$8I (1946). 
Similar principles seem to have governed the draftsmen in preparing the State Version, the alternative Section I-I05 of the May I950 draft. Under that Section, the Articles of the Code are made applicable whenever any one of a list of acts or events occurs or is to occur within "this state." Why not use the same technique for interstate transactions? The Federal Version might then read like this, for example, for the Sales Article: ${ }^{24}$

(2) The Articles on Sales ... apply whenever any contract or transaction within the terms of any one of the Articles is made or occurs after the effective date of this Act and the contract

(a) is made, offered or accepted or the transaction occurs within any State or Territory or within federal territory; or

(b) is to be performed or completed wholly or in part within any State or Territory or within federal territory; or

(c) relates to or involves goods which are to be or are in fact delivered, shipped or received within any State or Territory or within federal territory; . . . unless all of those points of contact are limited to a single State or Territory.

The Federal Version should also apply, as it did in the May I949 draft, to any contract which states that it is subject to the Uniform Commercial Code. The parties could then resolve any ambiguities as to what law governs, and could by agreement make the rules for their local agreements conform to those for their interstate transactions. Statutory authority for such an agreement is unnecessary in so far as the agreement merely adopts terms of the contract, but it seems desirable to permit adoption of rules such as the Statute of Frauds, which cannot be changed by agreement. As to such rules, adoption by agreement might be justified by principles of the conflict of laws, but clarity and certainty would be served if Congress expressly authorized adoption as an incident to Congressional regulation of interstate commerce. The provision would be used for the most part in contracts which "affect" interstate commerce because one or both of the parties was engaged in interstate commerce. But to preserve simplicity of coverage and avoid technicalities, no jurisdictional limits should be added.

There is precedent for such permissive regulation, applicable only when the parties adopt it. The United States Warehouse $\mathrm{Act}^{25}$ authorizes the Secretary of Agriculture to license warehousemen who apply; it regulates only licensed warehouses. Warehousemen not licensed under the Act are subject to state law; but the federal law, when it applies, ousts state regulation of the same matters. ${ }^{26}$ The Carriage of Goods by Sea Act ${ }^{2 \tau}$ applies only to transportation between United States ports and ports in foreign countries, and to cargo from loading to discharge; but the

\footnotetext{
26 Italies indicate insertions made in the Spring 1950 text of the Federal Version. Subparagraph (a) of that text has been omitted and the other subparagraphs relettered.

${ }^{26} 39$ STAт. 486 (I9I6), as amended, 7 U. S. C. $\$ \$ 241-273$ (1946).

${ }^{20}$ Rice v. Santa Fe Elevator Corp., 33I U. S. 218 (1947); In re Farmers Cooperative Ass'n, 69 S. D. I91, 8 N. W. 2d 557 (1943).

${ }^{27} 49$ STAT. 1207 (1936), 46 U. S. C. $\$ \$ 1300-1315$ (1946).
} 
bill of lading may and usually does provide that the Act shall apply in coastwise trade, before loading and after discharge. ${ }^{28}$ Again, admiralty had no jurisdiction to foreclose a ship mortgage before the Ship Mortgage $\mathrm{Act}^{20}$ was enacted; under that Act, if certain formalities are met, the parties may make a "preferred mortgage" on a ship, over which the admiralty will have exclusive jurisdiction. ${ }^{30}$ If a mortgage is not within the Act, there is still no jurisdiction in admiralty to foreclose it. ${ }^{31}$

The Supreme Court sustained the permissive extension of the admiralty jurisdiction under the Ship Mortgage Act, on the ground that it was constitutionally "necessary and proper" for carrying into execution the judicial power in cases of admiralty and maritime jurisdiction. ${ }^{32}$ It seems that permissive extension of the proposed Code is equally "necessary and proper" for the carrying into execution of the legislative power to regulate interstate commerce. The objective there was the encouragement of investment in shipping; the justification here is to free interstate commerce from confusion and doubt as to what law governs. This proposal may not go so far as might be permitted under the "affect" clause attacked above; and it has none of the indefiniteness of that clause.

\section{III}

\section{Government Contracts}

The duties imposed on the United States and the rights acquired by it by virtue of its contracts are at present governed by federal law. ${ }^{33}$ Where Congress has not adopted a different standard, it is customary for the federal courts to apply "the principles of general contract law."34 Those principles may be found in "the federal law merchant, developed for about a century under the regime of Swift $v$. Tyson," in the general commercial law applied in state and federal courts, ${ }^{30}$ or in uniform

${ }_{46}^{28}$ U. S. C. $\$ \$ 130 r(e)$, I3II, I3r2; see The Vale Royal, 5r F. Supp. 412, 424 (D. Md. I943); KnaUth, Ocean Bills of Lading, 90, 132-138 (3d ed. I947).

${ }^{20} 4$ I STAT. 1000 (x920), as amended, 46 U. S. C. \$\$9II-984 (1946).

${ }^{30}{ }_{46}$ U. S. C. $\$ \$ 922,951$; Detroit 'Trust Co. v. The Barlum, 293 U. S. 15 (1934); see Lord \& Glenn, The Foreign Ship Mortgage, 56 YALE L. J. 923 (1947).

${ }^{32}$ See Detroit Trust Co. v. The Barlum, supra note 30, 293 U. S. at 42.

${ }^{32}$ Ibid.

${ }^{83}$ See Royal Indemnity Co. v. United States, $3{ }_{3}$ U. S. 289,296 (194I) (interest recoverable on surety bond filed by taxpayer); United States v. Bethlehem Steel Corp., 315 U. S. 289, 299 (I942) (duress in shipbuilding contract of U. S. Shipping Board Merchant Fleet Corporation; applicability of state law left open); D'Oench, Duhme \& Co. v. FDIC, 315 U. S. 447, 456 (1942) (defense to note held by FDIC); Clearfield Trust Co. v. United States, 318 U. S. 363,366 (1943) (delay in discovering forged indorsement on government check); United States v. Allegheny County, 322 U. S. 174, 183 (1944) (title of United States to machinery purchased but not delivered); National Metropolitan Bank v. United States, 323 U. S. 454, 456 (I945) (forged indorsement on government check); Federal Crop Ins. Corp. v. Merrill, 332 U. S. 380 (I947) (effect of representations of agent of FCIC on crop insurance); Pricbe \& Sons v. United States, 332 U. S. 407, 4II, 4I4, 42I (r947) (penalty clause in purchase of eggs by Federal Surplus Commodities Corp.); cf. United States v. Standard Oil Co., 332 U. S. 301,305 (1947). See Note, 59 Harv. L. REv. 966 (I946).

${ }^{34}$ See Priebe \& Sons v. United States, supra note 33.

${ }^{35}$ See Clearfield Trust Co. v. United States, stpra note 33.

${ }^{30}$ See Frankfurter, J., dissenting in United States v. Bethlehem Steel Corp., stupra note 33, 315 U. S. at 326-30; Jackson, J., concurring in D'Oench, Duhme \& Co. v. FDIC, sipra note 33, 315 U. S. at 472; National Metropolitan Bank v. United States, supra note 33,323 U. S. at 454 . 
statutes widely enacted by the states. ${ }^{37}$ Sometimes the federal rule may adopt the law of a state ${ }^{38}$ or foreign nation ${ }^{39}$ in which part of the transaction occurs.

The Spring I950 draft of the proposed Code is apparently intended to apply to contracts of the United States otherwise within its terms. Section I-20r defines "person" to include "organization," and "organization" to include "government or governmental sub-division or agency." It defines "contract" in terms of "parties," and "party" in terms of "person." Section 2-ro3(I) defines "buyer" and "seller" in terms of "a person." And Section 4-ro5 indicates that "customer" and "item" include the United States and its checks, for it defines "payor bank" to include a bank which has agreed "with a customer to have his items drawn through it except where the customer is ... the United States."

Yet the Federal Version of the scope provision makes no explicit reference to contracts of the United States. Many such contracts would doubtless be subject to the federal Code by virtue of their contacts with the District of Columbia or with such other "federal territory" as the Brooklyn Navy Yard or the New York Post Office. ${ }^{40}$ The provision for commercial paper which is "to be performed within federal territory," which does not correspond to any provision in the State Version, may indicate that the draftsmen relied on such contacts for coverage of government contracts. But not all contracts of the United States are made, offered, accepted, or performed in federal territory. ${ }^{41}$ Thus checks drawn on the Treasurer of the United States "payable through Federal Reserve Banks" are paid by the designated bank "as agent and in behalf of the Treasurer"; 42 it could easily be argued that such a check was not commercial paper to be performed in federal territory, unless the Federal Reserve Bank is located in a federal enclave. Nor do transactions with the United States necessarily constitute or even "affect" interstate commerce."3

${ }^{37}$ Whitin Machine Works v. United States, I75 F. 2d 504, 507 (Ist Cir. 1949) (Uniform Sales Act); New York, N. H. \& H. R. R. v. Reconstruction Finance Corp., I80 F. 2d 24r, 244 (2d Cir. I950) (Negotiable Instruments Law).

${ }^{38}$ Royal Indemnity Co. v. United States, supra note 33 ; see Clearfield Trust Co. v. United States, stipra note 33, 318 U. S. at 367; United States v. Standard Oil Co., supra note 33,332 U. S. at 308.

${ }^{30}$ United States v. Guaranty Trust Co., 293 U. S. 340 (1934) (forged indorsement of Yugoslav payee of government check), distinguished in Clearfield Trust Co. v. United States, supra note 33.

10 "The Congress shall have Power ... To exercise exclusive Legislation . . . over all Places purchased by the Consent of the Legislature of the State in which the Same shall be, for the Erection of Forts, Arsenals, dock-Yards, and other needful Buildings; . . ." U. S. Consr., Art. I, §8, cl. 17. See McCarthy v. R. G. Packard Co., I05 App. Div. 436, 438, 94 N. Y. Supp. 203, 205 (Ist Dep't I905), affirmed, 182 N. Y. 555,75 N. E. I1 30 (xg05) (Brooklyn Navy Yard); James Stewart \& Co. v. Sadrakula, 309 U. S. 94, 97 (1940) (post-office site in New York City); of. Pacific Coast Dairy, Inc. v. Department of Agriculture of California, 318 U. S. 285, 294 (r943) (Moffet Field); Johnson v. Yellow Cab Co., 321 U. S. 383 (1944) (Fort Sill); S. R. A., Inc. v. Minnesota, 327 U. S. 558, 562 (1946).

${ }^{21}$ Cf., e.g., Penn Dairies, Inc. v. Milk Control Commission of Pennsylvania, 3I 8 U. S. 257, 267 (1943) (contract to sell milk to Army camp).

3 I C. F. R. $\$ 202.25(3)(2)$ (i) (Supp. I949); cf. Clearfield Trust Co. v. United States, 3 I 8 U. S. 363 , 364 (1943).

13 Employees of contractors with the United States were held not engaged in commerce or the production of goods for commerce under the Fair Labor Standards Act in Murphy v. Reed, 335 U. S. 865 (1948); Cooper v. Rust Engineering Co., I8r F. 2d 107 (6th Cir. I950); cf. Powell v. United States Cartridge Co., 339 U. S. 497 (1950); Englert v. S. Birch \& Sons Const. Co., I63 F. $2 d 34$ (9th Cir. 
It seems clear that contracts of the United States will not be controlled by the proposed Code as adopted by the states, except as the federal courts choose to look to the Code for the rules of general commercial law. Thus the proposal as it now stands would subject some government contracts to the federal Code and leave others untouched. The law for government checks and procurement contracts would vary with the geographical setting, contrary to the considered judgment of the Supreme Court of the United States. ${ }^{44}$

Whether the federal Code should cover contracts of the United States is a matter that can be argued both ways. There is much appeal in Mr. Justice Holmes's dictum that a previous case did not "mean that great business houses are held to less responsibility than small ones. The United States does business on business terms." ${ }^{45}$ The present law holds the United States to less responsibility than private business houses on many points. ${ }^{46}$ The proposed Code might impose on the United States a duty to cooperate in performance of its contracts, ${ }^{47}$ an obligation of good faith, ${ }^{48}$ and a liability in cases of forged indorsement, ${ }^{40}$ not found in the present law. Perhaps those changes are desirable.

But Mr. Justice Holmes also said that "Men must turn square corners when they deal with the Government." ${ }^{\text {"50 }}$ That requirement is designed to protect the public treasury from depletion not authorized by Congress. If the rules of the Code are to relax the safeguards, it would be well to be sure just what the effect would be. At the least, it would seem wise to ask contracting agencies of the United States to examine the Code with an eye to its effect on their operations.

It may be that such examination would show that government checks should be covered, for example, but that procurement for the armed services should not. It seems clear that geographical considerations would not be important. In any event, the matter should be disposed of explicitly. Ambiguity cannot be justified here on the ground that the contracts of the United States are unimportant or small.

r947), cert. denied, 332 U. S. 816 (1947); Crabb v. Welden Bros., I64 F. 2d 797 (8th Cir. I947); Maitrejean v. Metcalfe Construction Co., r65 F. 2d 571 (8th Cir. 1948); McDaniel v. Brown \& Root, Inc., I72 F. 2 d 466 (Ioth Cir. 1949); Selby v. J. A. Jones Const. Co., I75 F. 2d 143 (6th Cir. 1949). Unfair labor practices of such a contractor were held not to affect commerce in National Labor Relations Board v. Idaho-Maryland Mines Corp., 98 F. 2d I29 (9th Cir. 1938).

" See Clearfield Trust Co. v. United States, 318 U. S. 363,367 (1943); United States v. Allegheny County, 322 U. S. 174, 183 (r944); of. United States v. Standard Oil Co., 332 U. S. 30r, 305-11 (1947).

${ }^{4}$ See United States v. National Exchange Bank, 270 U. S. 527,534 (1926), relied on in Clearficld Trust Co. v. United States, 318 U. S. 363,369 (1943).

${ }^{\circ}$ E.g., Federal Crop Ins. Corp. v. Merrill, 332 U. S. 380 (1947) (representations of insurance agent).

${ }^{47}$ Compare U. C. C. $\$ 2-3 \operatorname{II}(3)$ (b) (Spring I950 draft) with United States v. Blair, 32I U. S. 730 (I944); United States v. Howard P. Foley Co., 329 U. S. 64 (1946).

${ }^{8}$ Compare U. C. C. $\$ \$ I-201(18)$, I-203 (Spring I950 draft) with United States v. Blair, stipra note 47; Federal Crop Ins. Corp. v. Merrill, supra note 46.

${ }^{40}$ Compare U. C. C. $\$ \$ 3-405(I)(c), 3-406$ and comment $7,4-205$ and comment 8 (Spring r950 draft) with Clearfield Trust Co. v. United States, 318 U. S. 363 (r943); National Metropolitan Bank v. United States, 323 U. S. 454 (I944).

${ }^{50}$ Rock Island, Arkansas \& Louisiana R. R. v. United States, 254 U. S. I41 (1920), relied on in Federal Crop Ins. Corp. v. Merrill, 332 U. S. 380, 385 (1947); see Frankfurter, J., dissenting in United States v. Blair, 321 U. S. 730, 738 (1944). 


\section{IV \\ JuRIsdiction of Federal Courts}

The American Bar Association Committee in $189 \mathrm{I},{ }^{51}$ as one of its objections to uniformity by act of Congress, raised this question:

If the Supreme Court of the United States has been clogged with the litigations of fifty millions of people on matters over which it now has jurisdiction, what would be the condition of its docket should the soon coming one hundred million double the subjects of its jurisdiction?

The problem of clogged dockets is raised by the proposed Code as to federal district courts as well as the Supreme Court.

The Spring $195^{\circ}$ draft contains no provision concerning the jurisdiction of federal courts. It is proposed as a regulation of commerce; claims under it would seem clearly to fall within Section 1337 of the Judicial Code, giving the federal district courts original jurisdiction, regardless of the amount in controversy, "of any civil action or proceeding arising under any Act of Congress regulating commerce. ..." Unless otherwise provided by Act of Congress, therefore, Section I44I(a) would allow the defendant to remove such an action from a state court to a federal court, as a "civil action brought in a State court of which the district courts of the United States have original jurisdiction. ..." Under Section I44I(b), the action would be removable "without regard to the citizenship or residence of the parties," as one "founded on a claim or right arising under the ... laws of the United States."

The volume of litigation under the Federal Version will depend in part on its coverage. The broader the coverage, the greater the danger that a flood of litigation will swamp the federal courts. It may be desirable to have important interstate transactions litigated under a uniform system of procedural as well as substantive law. But no reason appears for transferring to the federal courts any large proportion of the petty commercial cases now handled by state courts.

This problem has arisen before. One remedy is to prohibit removal, as is done for actions arising under the Federal Employers Liability $\mathrm{Act}^{52}$ and the Jones Act. ${ }^{53}$ Another is to prohibit removal "unless the matter in controversy exceeds $\$ 3,000$, exclusive of interest and costs," as is done for claims for damages against a common carrier for delay, loss, or injury to shipments, arising under the Carmack Amendment. ${ }^{54}$ Under the Federal Employers Liability Act, removal is not permitted for diversity of citizenship $;^{55}$ when a claim under the Carmack Amendment exceeds $\$ 3,000$, removal may be made on the ground of diversity as well as on the ground

52 See note 7 , supra, at 374 .

${ }^{52} 45$ U. S. C. $\$ \$ 4 I-50$. Section $1445($ a) of the Judicial Code prohibits removal.

${ }^{53} 46$ U. S. C. $\$ 688$. The statute adopts for seamen the provisions made for railway employees by the Federal Employers Liability Act; with those provisions go the prohibition on removal. E.g., Moltke v. Intercontinental Shipping Corp., 86 F. Supp. 662 (S. D. N. Y. 1949).

s6 49 U. S. C. $\$ 20(\mathrm{II})$. Section 1445 (b) of the Judicial Code limits removal as quoted:

${ }^{t t}$ Kansas City Southern Ry. v. Leslie, 238 U. S. 599 (1915). 
that the action arises under the Act of Congress. ${ }^{50}$ Both provisions permit original suit in a federal court without regard to amount. ${ }^{57}$

Under the Fair Labor Standards Act action may be brought in a federal court without regard to amount in controversy, ${ }^{58}$ but the right of removal has been left in doubt by a provision that action "may be maintained in any court of competent jurisdiction." "59 Numerous conflicting decisions have been made by district courts; the only case in an appellate court holds that that language prevents removal. ${ }^{.0}$ That case was decided before the new Judicial Code went into effect, and it is not clear whether the quoted language is "express" within Section I44I of the Judicial Code, permitting removal "except as otherwise expressly provided by Act of Congress."

Actions by employees against their employers may be thought to involve an inequality of position which justifies permitting the plaintiff to choose the forum. The same may conceivably be said of an action by a shipper against a common carrier. No such consideration is present in the proposed Uniform Commercial Code; if federal jurisdiction is to be limited, the limitation should apply equally to the original and the removal jurisdiction. The obvious course would be to require the amount in controversy to exceed $\$ 3,000$ in both cases. Actions by or against the United States should of course not be subject to such a limitation. Such a limitation, coupled with a restriction to interstate transactions, should prevent any great shift of litigation to federal courts. For interstate transactions are likely to involve citizens of different states; if the amount in controversy is more than $\$ 3,000$, diversity of citizenship now gives federal jurisdiction.

The jurisdiction of the Supreme Court is less troublesome, at least if the Federal Version is not so drawn that every petty case raises a constitutional problem. Appeals may be taken when a federal court of appeals holds a state statute repugnant to the laws of the United States, when a state court holds a statute of the United States invalid, or when a state court holds a state statute valid against a claim that it is repugnant to the laws of the United States. ${ }^{61}$ But in most cases review is by writ of certiorari, discretionary with the Court, as where in a state court "any title, right, privilege or immunity is specially set up or claimed under the ... statutes of . . . the United States." ${ }^{62}$ There might be some increase in the business of the Supreme Court if the proposed Code were enacted. But the Rules of the Court would permit it to decline to review any but the most important questions unless conflicts of decision arose. And the power of a single Court of nation-wide jurisdiction to resolve such conflicts would make possible the realization of the goal of a uniform commercial law.

\footnotetext{
${ }^{60}$ Cf. Southern Pacific Co. v. Stewart, 245 U. S. 359, 562 (19r8).

${ }^{57}$ Peyton v. Railway Express Agency, 316 U. S. 350 (1942) (Carmack Amendment).

${ }^{88}$ See Williams v. Jacksonville Terminal Co., 315 U. S. 386, 390 (1942).

8029 U. S. C. \$2I6(b).

${ }^{00}$ Johnson v. Buter Bros., I62 F. 2d 87 (8th Cir. 1947).

ex Judicial Code $\$$ I254(2), I257(1), (2).

${ }^{02}$ Judicial Code \$1257(3); Supreme Court of the United States, Rule 38(5).
} 


\section{Conclusion}

This comment may seem severely critical. It would serve no useful purpose if it did no more than sing the praises of the Uniform Commercial Code. It reflects a clear belief that the Federal Version of the scope section is not satisfactory in the Spring $195^{\circ}$ draft. To avoid misunderstanding, however, I hereby dissociate myself from Professor Williston's view that the defects are so fundamental that they cannot be cured. ${ }^{63}$ The project seems to me a worthy and a needed one; its execution seems to me on the whole to be wisely done and in parts brilliantly done. I hope to become a proponent.

But the scope of federal enactment seems to me vital. Without federal enactment, Professor Williston's prediction of confusion seems sound; unsound federal enactment might be worse than none. My theses are four:

(r) A state should not enact the Code unless there is reasonable assurance that it will shortly be enacted by Congress.

(2) Federal coverage should be limited to transactions truly interstate or foreign, except by consent of the parties; and its scope should be precise.

(3) Contracts to which the United States is a party should be provided for expressly and without regard to geography.

(4) The jurisdiction of the federal courts under the Code should be limited to avoid denial of justice by delay.

If these theses are accepted, changes must be made.

${ }^{63}$ See Williston, The Law of Sales in the Proposed Commercial Code, 63 HARv. L. Rev. 56I (1950). 